\title{
MEDICAL SCIENCES
}

\section{MODERN REQUIREMENTS TO THE EDUCATIONAL- PROFESSIONAL PROGRAM FOR MASTERS OF THE SECOND LEVEL OF HIGHER EDUCATION IN THE DISCIPLINE «DERMATOVENEREOLOGY» IN THE SPECIALTY «DENTISTRY»}

\author{
Oksana Kuhta $^{1}$ \\ Khrystyna Nykolaichuk ${ }^{2}$
}

DOI: https://doi.org/10.30525/978-9934-26-076-6-3

A competent doctor is a future in world medicine. What is competence? Competence translated from Latin «competentia» means a range of issues in which a person is well aware, has knowledge and experience. A person, competent in a certain field, has the appropriate knowledge and abilities that allow him to reasonably judge this field and act effectively in it [1;2]. Competence is also defined as the integrated ability of an individual acquired in the process of learning, which consists of knowledge, experience, values, and attitudes that can be fully implemented in practice.

In the methods of teaching certain subjects of competence have been used long ago, for example, linguodidactic competencies are used in languages, communicative - in computer science. In recent years, the concept of «competence» has reached the general didactic and methodological level [3]. This is due to its system-practical functions and integrative meta-subject role in general education. Increased attention to this concept is also due to the recommendations of the Council of Europe concerning the restoration of education, its approximation to the order of society. The need for the formation of key competencies by the school is noted in the conceptual modernization of national education[4; 5].

The educational-professional program is a normative document in medicine, which regulates the normative competence, qualification, organizational, educational, and methodological requirements for the preparation of masters in the field of 22 «Health» specialty 221 «Dentistry». The educational and professional program is based on the competency

\footnotetext{
${ }^{1}$ Ivano-Frankivsk National Medical University, Ukraine

${ }^{2}$ Ivano-Frankivsk National Medical University, Ukraine
} 
approach of training a specialist in the field of 22 «Health» specialty 221 «Dentistry»[6].

Educational-professional program Dentistry of the second (master's) level of higher education in the specialty 221 «Dentistry», field of knowledge 22 Health care is developed in accordance with the Law of Ukraine «On Higher Education», Standard of higher education in specialty 221 «Dentistry» in the field of knowledge 22 Health care «for the second (master's) levels of higher education, Resolution of the Cabinet of Ministers of 29.04.2015 № 266» On approval of the list of branches of knowledge and specialties in which higher education is trained «, Resolution of the Cabinet of Ministers of Ukraine of 23.11.2011 № 1341 «On approval of the National Qualifications Framework» as amended in accordance with the Resolutions of the Cabinet of Ministers of 12.06.2019 № 509, 25.06.2020 № 519, Resolution of the Cabinet of Ministers of Ukraine of 28.03.2018 № 334 «On approval of the Procedure for a single state qualification examination for applicants for a master's degree in the field of knowledge «Health», the Resolution of the Cabinet of Ministers of Ukraine from 12/30/2015 № 1187 «On approval of the Licensing Conditions for educational activities of educational institutions» and other applicable regulations. The educational-professional program is a normative document, which defines the profile of the educational-professional program in the specialty 221 «Dentistry», the list of program components and their logical sequence, the number of ECTS credits required for this program, the form of certification of higher education [7; 8].

The discipline «Dermatovenereology» is a clinical course, the subject of which is the examination of a patient with the pathology of the skin and mucous membranes of the mouth and genitals, the study of the leading syndromes and symptoms in dermatovenereology, manifestations of skin and venereal diseases in the mouth, nature, and principles of treatment, complications of the most common diseases, providing emergency and specialized care, measures of primary and secondary prevention of the most common skin and sexually transmitted diseases.

The specifics of teaching Dermatovenereology at the Faculty of Dentistry include direct medical orientation, prevention, and treatment of patients with affections of the oral mucosa, which are often an important symptom of many skin and sexually transmitted diseases. When studying the discipline, dentists should pay special attention to dermatoses, which often (lichen planus, herpes, exudative erythema, cheilitis, lupus erythematosus, candidiasis, pemphigus, etc.) or in isolation (tuberculosis, leprosy) appear on the oral mucosa and lips, as well as widespread (pyoderma, dermatitis, urticaria, toxiderma) to provide counseling or emergency care. Disclosure of the place of the academic 
discipline in the structural-logical scheme of the educational-professional program (EPP).

The purpose of teaching the discipline «Dermatovenereology» is to prepare students to work as a family doctor, able to diagnose major diseases of the mouth, lips, and skin in adults and children, provide specialized care, prevention of the most common skin diseases [9].

The discipline «Dermatovenereology» is aimed at mastering the following competencies by students [10; 11]:

- Integral competence (IC): the ability to solve complex problems and problems in the field of health care in the specialty 221 «Dentistry» in professional activities or the learning process, which involves research and/or innovation and is characterized by the uncertainty of conditions and requirements.

- General competencies (GC) are:

1. Ability to improve professional skills.

2. Ability to use information and communication technologies.

3. Ability to search, process, and analyze information from various sources.

4. Ability to identify, pose and solve problems.

5. Ability to communicate in a professional environment and with representatives of other professions in the national and international context.

6. Ability to evaluate and ensure the quality of work performed.

7. Ability to work in a team.

- Special (professional) competencies (PS) are:

PC 1. Ability to collect medical information about the patient and analyze clinical data.

PC 2. Ability to interpret the results of laboratory and instrumental research.

PC 3. Ability to diagnose: determine the preliminary, clinical, final, concomitant diagnosis, emergencies.

Competence is a dynamic combination of knowledge, skills, and practical skills, ways of thinking, professional, ideological, and civic qualities, moral and ethical values, which determines a person's ability to successfully carry out professional and further educational activities and is the result of higher education.

\section{References:}

1. Resolution of the Cabinet of Ministers of Ukraine of 23.11.2011 № 1341 «On approval of the national qualifications framework».

2. Resolution of the Cabinet of Ministers of Ukraine of April 29, 2015, № 266 «On approval of the list of branches of knowledge and specialties in which higher education students are trained». 
3. ISCED Fields of Education and Training 2013 (ISCED-F 2013). Available at: http://www.uis.unesco.org/Education/Documents/isced-fields-of-education-training 2013.pdf.

4. Law of Ukraine «On Higher Education». Available at: http://zakon4.rada.gov.ua/laws/show/1556-18

5. National Classifier of Ukraine: «Classifier of Professions» DK 003: 2010. Kyiv: Publishing House «Sotsinform», 2010.

6. National Qualifications Framework. Available at: http://zakon4.rada.gov.ua/ laws/show/1341-2011-p

7. List of branches of knowledge and specialties for which higher education seekers are trained. Available at: http://zakon4.rada.gov.ua/laws/show/266-2015-p.

8. Order of the Ministry of Education and Science of Ukraine dated 01.06.2016 № 600 «On approval and implementation of Guidelines for the development of standards of higher education»

9. Methodical recommendations for the development of standards of higher education / Approved by the higher education sector of the Scientific and Methodological Council of the Ministry of Education and Science of Ukraine protocol № 3 from 29.03.2016

10. Standards and Guidelines for Quality Assurance in the European Higher Education Area (ESG). Available at: http://ihed.org.ua/images/pdf/standards-and guidelines_for_qa_in_the_ehea_2015.pdf

11. International Standard Classification of Education (ISCED 2011). Available at: http://www.uis.unesco.org/education/documents/isced-2011-en.pdf. 